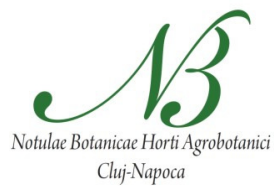

\title{
Molecular and Elemental Characterization of Selected Turkish Durum Wheat Varieties
}

\author{
Erdogan E. HAKKI ${ }^{1}$, Nurdan DOGRAR ${ }^{2}$, Anamika PANDEY ${ }^{1}$, \\ Mohd. Kamran KHAN ${ }^{1}$, Mehmet HAMURCU ${ }^{1}$, Seyit A. KAYIS ${ }^{3}$, \\ Sait GEZGIN ${ }^{1}$, Fatih ÖLMEZ ${ }^{4}$, Mahinur S. AKKAYA ${ }^{2 *}$ \\ ${ }^{1}$ University of Selcuk, Department of Soil Science and Plant Nutrition, Konya, 42250, Turkey; eehakki@selcuk.edu.tr; anamika.biotech@gmail.com; \\ mohdkamran.biotech@gmail.com;mhamurcu@selcuk.edu.tr;sgezgin@selcuk.edu.tr \\ ${ }^{2}$ MiddleEastTechnical University,Department ofChemistry,Ankara, 06800,Turkey; a.biotech@yahoo.com; akkayams@metu.edu.tr(*orrespondingauthor) \\ ${ }^{3}$ University of Selcuk, Department of Animal Science, Biometry and GeneticsUnit, Konya, 42250,Turkey; skayis@selcuk.edu.tr \\ ${ }^{4}$ Central Research Institutefor Field Crops, Ankara,06170,Turkey; chotu.k@gmail.com
}

\begin{abstract}
Combination of elemental and protein studies along with molecular data using microsatellite markers may lead to the better and realistic determination of relatedness between the varieties and their populations. In this study, the extent of diversity among five Turkish durum wheat cultivars and their populations has been assessed using seven microsatellite markers and the elemental analysis together with the differences in their protein content. In molecular analysis, total 23 alleles have been obtained among all the genotypes with middling of 4.6 per primer. On employing UPGMA Dendrogram, Principle Coordinate Analysis (PCoA) and Winboot analyses, both inter and intra varietal polymorphic studies had shown similar clustering with minor differences. As a result of AMOVA performed, the extent of diversity was found to be higher among the genotypes (76\%) in comparison to the variability within the genotypes (24\%). In elemental analyses, 'Selcuklu-97' was found to be the most efficient variety with high content of several elements. Also, strong and positive correlation has been observed between magnesium- phosphorus, magnesium-sulphur and sulphur-sodium, while noteworthy negative correlation has been observed between sodium and zinc. The protein content of the genotypes was found in the range of $15.17-16.90 \%$. The diversity revealed in durum genotypes can be employed in genetic expansion of the crop. These involved varieties may aid to avoid genetic attrition coming up from the landraces. The information provided can be utilized by breeders for appropriate selection of both, genetically and nutritionally efficient durum wheat varieties.
\end{abstract}

Keywords: elemental analysis, genetic diversity, grain protein, microsatellites, tetraploid wheat

\section{Introduction}

Durum wheat (Triticum turgidum L. subsp. durum (Desf.) Husn) is renowned as the only commercially important tetraploid wheat species that is extensively cultivated in the Mediterranean region, Canada, USA, Argentina and India (Blanco et al., 1998). Around 7000 B.C., domesticated emmer wheat strains which were previously grown in the Near East and Central Europe (Zohary and Hopf, 1993), were artificially selected and lead to the development of naked, free-threshing form of Durum species. Prevalently known to be used in the preparation of Italian pasta, durum wheat possesses rich protein content and is hardest among all the wheat types. Durum wheat has gained its importance amidst bread wheat due to the predominant suffering of developing countries from food scarcity and lack of fine stuff that can be used in the food sector (Korkut et al., 2007). So, durum wheat breeding programs should be designed to suggest cultivars with adequate agronomic characteristics to meet the demand of the farmers and the quality traits required by the processing industry. Our study was an effort to provide some relevant information to the researchers and breeders on selected durum wheat varieties, so that their practical usage and benefits can be estimated and implemented for fulfilling both qualitative and quantitative agricultural demands.

\section{Molecular characterization}

Several views have revealed that the discriminatory strain of the variations in the environment, individual behaviour, continuous domestication and the rigorous breeding are basically responsible for the prearrangement of precise diversity level among wheat (Donini et al., 2000; Amer et al., 2001; Landjeva et al., 2006; Figliuolo et al., 
2007). Then also, the evaluation of genetic diversity has been decisive in breeding programs for the choice of suitable parents to gain heterotic hybrids, and for the investigation of new germplasm (Prasad et al., 2000). Marker systems based on different wheat properties like protein content, flour colour, gluten strength has facilitated the upgrading of durum quality (Nachit et al., 2001; Maccaferri et al., 2006). Other than these properties, genetic diversity studies of diverse accessions is strengthen by the advancement and thriving appliance of various types of molecular markers (Khan et al., 2014). For more than two decades, simple sequence repeats (SSRs) or microsatellite markers (Tautz et al., 1986) have been progressively used for diversity analysis of native and contemporary cultivars (Todorovska et al., 2005; Al Khanjari et al., 2007; Colomba and Gregorini, 2011) and has shown promising polymorphism.

Thus, the goal of the molecular part of present study was to evaluate genetic similarity along with the evaluation of the allelic diversity among five Turkish durum wheat genotypes. In this research work, analyses of population structure and comparison of diversity level between landraces and cultivars has also been done by the exploitation of available SSR markers and were used for invariety polymorphism detection of cultivars. Most of the optimization reactions and conditions are explained thoroughly to provide supportive platform to the researchers and developing scientists in this area. Comparing our normalization, they may standardize their protocols and molecular experiments to raise a new step towards this scientific horizon.

\section{Elemental characterization}

Not only genetic constitution is crucial, but also nutrients $(\mathrm{Mg}, \mathrm{Fe}, \mathrm{Zn}, \mathrm{P}, \mathrm{Na}, \mathrm{Ca}, \mathrm{K}, \mathrm{Cu}, \mathrm{Mn}$ ) and proteins are major gears of the plant enzymes controlling the physical and biochemical feedback. Indispensability of plant minerals in developing the resistance against diseases and other environmental strains has been revealed by several researchers (Graham and Rovina, 1984; Graham and Webb, 1991; Foy, 1992; Lynch, 1995). Mineral extremities in plants are consequently influencing the animal and human system as well. Thus, the upgrading of nutrient contents in plants symbolizes a promising approach to enhance the human nutrient intake. Today, finding out the efficient connections between genes, mineral and proteins is amongst one of the biggest challenges for the scientists to deal with (Lahner et al., 2003). Because of the increased usage of wheat around the globe in a range of foodstuffs, it is taken as a vital source for nutrient supply (Galan and Haguenauer-Tsapis, 1997). Since last several years, diversity in mineral contents has been continuously depicted for various cereals including bread wheat, durum wheat, wild wheat and triticale (Dikeman et al., 1982; McGrath, 1985; Feil and Fossati, 1995; Cakmak et al., 2000; Clarke et al., 2002). A screening of more than 3000 GenBank wheat accessions has been done at CIMMYT for $\mathrm{Fe}$ and $\mathrm{Zn}$ contents. As we discussed earlier, durum wheat is the chief crop for making pasta, a major proportion is also used in bread preparation. The prospective contribution of durum wheat in the supply of minerals and to a less extent, proteins has developed a transformed interest in durum based food products. Considering this interest, breeding strategies should be developed for the choice of wheat varieties with appropriate mineral content.

So, here comes the objective for the biochemical part of our work (i) to evaluate the variation in mineral and protein content of Turkish durum wheat grains and (ii) to determine the correlation among the mineral and protein concentrations so that better-quality durum wheat cultivars with high mineral and protein amount can be identified and utilized.

\section{Materials and methods}

\section{Plant materials and DNA Extraction}

The pedigree information of five durum wheat varieties collected from different geographical regions of Turkey utilized in this study has been provided in Tab. 1. For each genotype, 10 individual plants had been grown in the greenhouse conditions up to seedling stage. To obtain pure and intact DNA, five different isolation procedures were tested (with both $1 \%$ and $2 \%$ CTAB) and finally the modified form of the SaghaiMaroof et al., (1984) method has been utilized. Freeze-dried seedlings $(200 \mu \mathrm{g})$ of all individual plants were homogenized in liquid nitrogen and dispersed in $700 \mu \mathrm{L}$ isolation buffer $(2 \%$ CTAB w/v, $1.4 \mathrm{M} \mathrm{NaCl}, 20 \mathrm{mM}$ EDTA, pH 8.0, $100 \mathrm{mM}$ Tris, $\mathrm{pH} 8.0$ and $0.1 \% \beta$-mercaptoethanol) following the incubation at $65^{\circ} \mathrm{C}$ for 45 minutes by inverting several times. Afterwards equal amount of the 24:1 (v/v) chloroform:isoamyl alcohol was added and the mix was centrifuged at $7000 \mathrm{rpm}$ for 5 minutes. To the supernatant part, 0.6 volume isopropyl alcohol was added and centrifuged at 15,000 rpm for 5 minutes. Seventy percent alcohol was used to rinse the obtained pellet by spinning at a speed of 15,000 rpm for 5 minutes. The pellet was dissolved in $400 \mu \mathrm{L}$ TE buffer after drying of ethanol and stored at $-70^{\circ} \mathrm{C}$.

Isolated DNA samples were spectrophotometrically estimated at 230, 260 and $280 \mathrm{~nm}$ and accordingly, templates of $10 \mathrm{ng} / \mu \mathrm{L}$ and $30 \mathrm{ng} / \mu \mathrm{L}$ samples were prepared for polymerase chain reaction.

\section{Microsatellite analysis}

For the SSR analysis, seven different sets of Wheat Microsatellite (WMS) primers (Tab. 2) had been selected whose description, composition, sequences and chromosome positions of the augmented loci were already reported (Roder $e t$ al., 1995; Plaschke et al., 1995).

Optimized PCR reactions were performed in $10 \mu \mathrm{L}$ volume in Thermal Cycler and the constituents for the reaction mixture contained $1 X$ PCR buffer $(10 \mathrm{mM}$ Tris- $\mathrm{HCl}$ $\mathrm{pH}: 8.3,50 \mathrm{mM} \mathrm{KCl}), 0.10 \mathrm{mM}$ dNTP mixture $(10 \mathrm{mM}$ each), $1.5 \mu \mathrm{L}$ Taq polymerase (5 unit/ $\mu \mathrm{L}$ ), 5-10 pmol of forward and reverse primer combinations and $50 \mathrm{ng}$ to $150 \mathrm{ng}$ of template DNA per reaction. All primer pairs required $1.5^{\circ}$ $\mathrm{mM}$ of Magnesium Chloride $\left(\mathrm{MgCl}_{2}\right)$, while WMS30 required $2.0 \mathrm{mM} \mathrm{MgCl}_{2}$. Characteristic reaction conditions for each of the primer sets (microsatellite or SSR loci) repeat types and the chromosomal locations are represented in Tab. 2.

\section{Detection of microsatellites}

Denaturing polyacrylamide gel (6\%) and 1X TBE buffer was used to separate out the PCR products. To $60 \mathrm{ml}$ of $6 \%$ 
433

denaturing polyacrylamide gel solution, $650 \mu \mathrm{l}$ of $10 \%$ APS (Ammonium Persulfate) and $25 \mu$ l of TEMED (N,N,N',N'Tetramethylethylenediamine) were added to initiate the polymerization and poured between two sigmacoat treated glass plates $(42 \mathrm{X} 33 \mathrm{~cm})$. The PCR products were electrophoresed on the denaturing gels at a constant power of 50 Watt and the run time was modified according to the expected allele sizes. The obtained fingerprints were detected on autoradiographs (Kodak BioMax-MR, Rochester, NY).

\section{(PIC)}

Estimation of Polymorphism Information Content

According to Anderson et al. (1993), for the microsatellites which were homozygous for a loci, PIC values were obtained using the formula:

Tab. 1. Durum wheat varieties and their pedigrees

\begin{tabular}{ccl}
\hline No & \multicolumn{1}{c}{ Variety } & \multicolumn{1}{c}{ Pedigree } \\
\hline 1 & 'Diyarbakir-81' & $\begin{array}{l}\text { Ld393XbellE-Tehuacan }{ }^{2} \text { Cocorit71 } \\
\text { SE0364-1S-4S-0S }\end{array}$ \\
& & $\begin{array}{l}\text { Jori/Anhinga//Flamingo } \\
\text { CM9799-126M-1M-4Y-0M }\end{array}$ \\
2 & 'Ege-88' & Ld357E-Tehuacan ${ }^{2}$ xJori \\
& & 27534-1M-1Y-1M-0Y \\
3 & 'Gediz-75' & SHWA//21563/Anhinga/3/Ege88 \\
& & CD27672-4AP-1AP-4AP-0AP \\
4 & 'Salihli-92' & Akbasak-073-44*2/Ovi/3/DF21-72//61- \\
& & $130 /$ Üvy162 \\
& & YA0398621A-1A-5A-6A-0A \\
& &
\end{tabular}

$P I C_{i}=1-\sum_{j=1}^{n} p_{i j}^{2}$

where:

$p_{i j}$ is the frequency of the $j$ th pattern for marker $i$ for $n$ number of patterns. For the single locus revealing two allelic sizes, PIC values were calculated as follows:

$$
P I C_{i}=1-\left(\sum_{j=1}^{n} p_{i}^{2}\right)-\sum_{i=1}^{n-1} \sum_{j=i+1}^{n} 2 p_{i}^{2} p_{j}^{2}
$$

Here, $p_{i}$ and $p_{j}$ represent the frequencies of the $i$ th and $j$ th alleles in a given population.

\section{Cluster analysis}

For the determination of genetic distances, the band patterns obtained in the gel were utilized in two formats to prepare microsatellite data matrix. In one format, all the amplified bands were scored as 1 or 0 corresponding to the presence and absence of specific marker allele, respectively. While in another format, codominant data representing the allelic bands was utilized. Distance matrices employing these dominant and codominant data were prepared with the help of Numerical Taxonomy Multivariate Analysis System (NTSYSPC) version 2.02e (Rohlf, 1998) and GenAlEx 6.5 programs.

Dendrograms were constructed using Unweighted Pairgroup Arithmetic Average (UPGMA) (Sneath and Sokal, 1973) method and R software with the NTSYS-PC version $2.02 \mathrm{e}$ for the detection of polymorphism among the genotypes as well as among the subpopulations, respectively. Also, bootstrap analysis using Winboot program with 1000

Tab. 2. PCR Amplification Conditions, Primer Sequences and Chromosomal Locations of primer sets (modified from Roder et al., 1995 and Plaschke et al., 1995)

\begin{tabular}{|c|c|c|c|c|c|c|c|}
\hline \multirow{2}{*}{ Markers } & \multirow{2}{*}{ Primer Sequences } & \multirow{2}{*}{ Repeat Sequences } & \multirow{2}{*}{$\begin{array}{c}\text { Chromosomal } \\
\text { Location }\end{array}$} & \multicolumn{3}{|c|}{ PCR Conditions } & \multirow{2}{*}{ Cycles } \\
\hline & & & & $\mathrm{D}$ & $\mathrm{A}$ & $E$ & \\
\hline WMS5 & $\begin{array}{l}\text { 5'GCCAGCTACCTCGATAC } \\
\text { AACTC 3' } \\
\text { 5'AGAAAGGGCCAGGCTAG } \\
\text { TAGT 3' }\end{array}$ & $\begin{array}{c}(\mathrm{TC})_{23}(\mathrm{~T})_{4}(\mathrm{GT})_{12}( \\
\mathrm{GA})_{10}\end{array}$ & $3 \mathrm{~A}$ & & $50^{\circ} \mathrm{C} 1 \mathrm{~min}$ & & 32 \\
\hline WMS6 & $\begin{array}{l}\text { 5'CGTATCACCTCCTAGCT } \\
\text { AAACTAG 3' } \\
\text { 5'AGCCTTATCATGACCCT } \\
\text { ACCTT 3' }\end{array}$ & $(\mathrm{GA})_{40}$ & $4 \mathrm{~B}$ & & $55^{\circ} \mathrm{C} 1 \mathrm{~min}$ & & 35 \\
\hline WMS11 & $\begin{array}{l}\text { 5'GGATAGTCAGACAATTC } \\
\text { TTGTG 3' } \\
\text { 5'GTGAATTGTGTCTTGTA } \\
\text { TGCTTCC 3' }\end{array}$ & $\begin{array}{c}(\mathrm{TA})_{6} \mathrm{CATA}(\mathrm{CA})_{19} \\
(\mathrm{TA})_{6}\end{array}$ & $1 \mathrm{~B}$ & & $61^{\circ} \mathrm{C} 1.5 \mathrm{~min}$ & & 35 \\
\hline WMS30 & $\begin{array}{l}\text { 5'ATCTTAGCATAGAAGGG } \\
\text { AGTGGG 3' } \\
\text { 5'TTCTGCACCCTGGGTGA } \\
\text { T 3' }\end{array}$ & $(\mathrm{AT})_{19}(\mathrm{GT})_{15}$ & $3 \mathrm{~A}$ & $\begin{array}{l}94^{\circ} \mathrm{C} \\
1 \mathrm{~min}\end{array}$ & $58.5^{\circ} \mathrm{C} 1 \mathrm{~min}$ & $\begin{array}{c}72^{\circ} \mathrm{C} \\
1.5 \mathrm{~min}\end{array}$ & 35 \\
\hline WMS46 & $\begin{array}{l}\text { 5'GCACGTGAATGGATTGG } \\
\text { AC 3' } \\
\text { 5'TGACCCAATAGTGGTGG } \\
\text { TCA 3' }\end{array}$ & $(\mathrm{GA})_{2} \mathrm{GC}(\mathrm{GA})_{33}$ & $7 \mathrm{~B}$ & & $58^{\circ} \mathrm{C} 1 \mathrm{~min}$ & & 30 \\
\hline WMS120 & $\begin{array}{l}\text { 5'GATCCACCTTCCTCTCT } \\
\text { CTC 3' } \\
\text { 5'GATTATACTGGTGCCGA } \\
\text { AAC 3' }\end{array}$ & $(\mathrm{CT})_{11}(\mathrm{CA})_{18}$ & $2 \mathrm{~B}$ & & $55^{\circ} \mathrm{C} 1 \mathrm{~min}$ & & 35 \\
\hline WMS131 & $\begin{array}{l}\text { 5'AATCCCCACCGATTCTT } \\
\text { CTC 3' } \\
\text { 5'AGTTCGTGGGTCTCTGA } \\
\text { TGG 3' }\end{array}$ & $(\mathrm{CT})_{22}$ & $1 \mathrm{~B}, 2 \mathrm{~B}$ & & $55^{\circ} \mathrm{C} 1 \mathrm{~min}$ & & 40 \\
\hline
\end{tabular}


replications, has been done to determine the confidence limits of UPGMA dendrogram. To illustrate the interrelationships with in populations, $\mathrm{R}$ software has been used to draw the scatterplots based on both dominant and codominant data.

Analysis of Molecular variance (AMOVA) has been utilized for the estimation of genetic construction among the population and subpopulations of genotypes. GenAlEx 6.5 program was used for the preparation of distance matrix to estimate the genetic variation and screen the total variation within and among the populations. One thousand permutations have been employed for testing the significance of variance components.

\section{Field growth conditions of the wheat genotypes}

Field experiment for the collection of seed material for elemental and protein analysis has been conducted in the year 2012 at Selcuk University, Konya, Turkey. Varieties collected from different regions have been grown in accordance with the randomized complete block design with several replications at trial site. Initially, sprinkler irrigation followed by periodical drip irrigation was provided to the plots. Sowing was done on 8th October, 2012 while plots were harvested manually on 13th July 2013.

\section{Methodology for the determination of mineral content}

For the elemental analysis of the selected genotypes, 8346 durum wheat flour and 1567a wheat flour were used as the certified reference material for calibrating ICP-AES values. Firstly, wheat grains were washed with double distilled water and dried at $70^{\circ} \mathrm{C}$ in a drying cabinet with air circulation. The dried samples were then ground to the whole wheat flour and $0.1-0.2 \mathrm{~g}$ was treated with $5 \mathrm{ml}$ concentrated $\mathrm{HNO}_{3}$ and $2 \mathrm{ml}$ of $\mathrm{H}_{2} \mathrm{O}_{2}$ in a digestion tube made of teflon. Further, the samples were digested in a closed microwave accelerating reaction system for 30 minutes. After digestion, each sample solution was filtered and the volume was maintained up to 20 $\mathrm{ml}$ with double distilled water. Finally, mineral concentrations of three technical replicates of each genotype were estimated using inductively coupled plasma-optical emission spectroscopy (ICP AES).

\section{Protein content analyses}

For protein analysis, Kjeldahl semi automatic analysis system was used. Wheat samples were crushed and $0.5 \mathrm{~g}$ sample of each variety was treated with $5 \mathrm{ml} \mathrm{H}_{2} \mathrm{SO}_{4}$ for one night. Then $1 \mathrm{ml}$ of hydrogen peroxide was added to samples several times with simultaneous wet digestion until the solution became transparent. Then Kjeldahl's apparatus was used to determine the acid $\left(\mathrm{H}_{2} \mathrm{SO}_{4}\right)$ value of three technical replicates of each genotype that further gave the idea of nitrogen contents in the sample. The nitrogen contents were multiplied by 6.25 to determine the protein content.

\section{Statistical analyses of the biochemical part}

Minitab Release 14.12.0 statistical software has been used for the comparison of the concentrations of different elements and to determine the correlations among them using Pearson correlation. The significance of these correlations was determined by 'p' value. As for both elemental and protein data, readings for three technical replicates have been taken, standard deviations were also calculated.

\section{Results and discussions}

By the evaluation of different isolation techniques tried, it was concluded that extraction buffer containing 2\% CTAB, resulted in high yield and intact genomic DNA quality in comparison to $1 \%$ CTAB. A previous study on hexaploid wheat (Roder et al., 1995) reported that WMS6 locus is located on 4DL and additional two fragments are located on 4DL and 4BL. So, since durum wheat does not possess the "D" genome, in our study, one of the allele of this locus must be the one located at $4 \mathrm{BL}$.

\section{Polymorphism level and genetic diversity among the genotypes}

The seven markers used in the study, covered a major part of durum wheat genome for the inter- or intra-diversification of five genotypes showing different allele sizes (Tab. 3). We obtained total 23 polymorphic alleles ranging from 1 to 8 per locus and PIC values in our study ranged from 0.227 to 0.887 . On calculating the PIC values based on the allelic frequencies, it was observed that WMS6 was the most polymorphic locus while WMS 131 was the least polymorphic with PIC value of 0.887 and 0.227 respectively (Tab. 4). Other than WMS 131, all the primers had PICs more than or equal to 0.500 . The length difference between allele sizes in base pair ranged from 4 to 48. The allele sizes obtained for different locus were also used to construct a Simple Matching similarity matrix (based on 0-1 data) for drawing the dendrogram for 5 different genotypes based on UPGMA (Unweighted Pair Group Method with Arithmetic Mean) method (Fig. 1). As Bootstrap analysis has been performed to demonstrate the robustness of UPGMA dendrogram, supports for clustering of 'Diyarbakir-81' with 'Salihli-92' and grouping of 'Ege-88' and 'Selcuklu-97' were found to be $100 \%$ and $90.7 \%$, respectively. Though 'Gediz-75' was clearly distinct from other genotypes (Fig. 1), it has shown a bootstraps support of $42 \%$ and found to be more closely associated with 'Diyarbakir-81' with 'Salihli-92'.

\section{Polymorphism levels 'In' and 'Among' the populations of each cultivar}

In the second part of the molecular research, the same microsatellite markers were used for in-variety polymorphism studies. The subpopulations might have different genotypes, thus, it was aimed to show the polymorphism levels, in about 10 individual plants belonging to each of the variety. The allele sizes of different individual plants at various loci were utilized to calculate PIC values (Tab. 5) and for the clustering of the

Tab. 3. Allele sizes of the used durum wheat genotypes, in number of nucleotides, for seven microsatellite markers

\begin{tabular}{|c|c|c|c|c|c|c|c|c|}
\hline No & Genotypes & $\begin{array}{c}\text { WMS } \\
5\end{array}$ & $\begin{array}{c}\text { WMS } \\
6\end{array}$ & $\begin{array}{c}\text { WMS } \\
11\end{array}$ & $\begin{array}{c}\text { WMS } \\
30\end{array}$ & $\begin{array}{l}\text { WM } \\
\text { S466 }\end{array}$ & $\begin{array}{c}\text { WMS } \\
120\end{array}$ & $\begin{array}{l}\text { WM } \\
\text { S131 }\end{array}$ \\
\hline 1 & 'Diyarbakir-81' & 163 & $\begin{array}{l}201 / \\
225\end{array}$ & 222 & 212 & 173 & 162 & 159 \\
\hline 2 & 'Ege-88' & 171 & $\begin{array}{l}199 / \\
213\end{array}$ & 220 & 216 & 181 & 162 & 159 \\
\hline 3 & 'Gediz-75' & 166 & $\begin{array}{l}201 / \\
211\end{array}$ & 222 & 214 & 181 & 159 & 159 \\
\hline 4 & 'Salihli-92' & 163 & $\begin{array}{l}199 / \\
205\end{array}$ & 222 & 212 & 173 & 162 & 159 \\
\hline 5 & 'Selcuklu-97' & 171 & $\begin{array}{l}203 / \\
247\end{array}$ & 228 & 216 & 169 & 162 & 159 \\
\hline & Difference(bp) & 8 & 48 & 8 & 4 & 12 & 3 & 0 \\
\hline
\end{tabular}


435

Tab. 4. PIC values, number of alleles and maximum length difference between allele sizes in base pair $(\Delta \mathrm{L})$ per locus for 5 different genotypes

\begin{tabular}{cccc}
\hline Primer Set & PIC values & No. of alleles & $(\Delta \mathrm{L})$ \\
\hline WMS5 & 0.611 & 3 & 8 \\
WMS6 & 0.887 & 8 & 48 \\
WMS11 & 0.500 & 3 & 8 \\
WMS30 & 0.611 & 3 & 4 \\
WMS46 & 0.666 & 3 & 12 \\
WMS120 & 0.500 & 2 & 19 \\
WMS131 & 0.227 & 1 & 4 \\
\hline
\end{tabular}

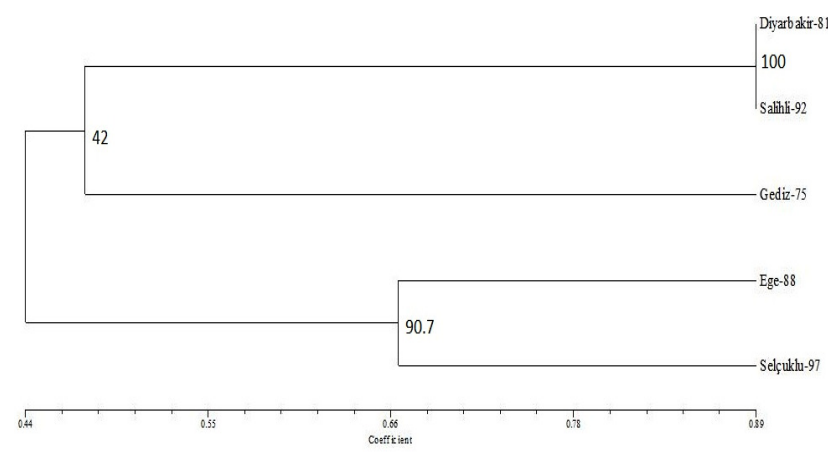

Fig. 1. Simple matching coefficient similarity matrix of microsatellite data set based UPGMA clustering of genotypes subpopulations using R software (Fig. 2). Tab. 6 demonstrates the PIC values per locus, number of alleles and maximum length difference between all allele sizes in base pair. The average highest and the lowest PIC values for cultivars was 0.391 and 0.105 for 'Diyarbakir-81' and 'Selcuklu-97', respectively (Tab. 6). The genotype 'Diyarbakur-81' has shown highest level of intra-polymorphism when compared to the other cultivars with WMS46 as the most polymorphic locus having average PIC value of 0.700 . In the similar way, the most polymorphic locus for 'Ege-88' population was WMS6 with the PIC value of 0.527 . There were four different genotypes observed in this population. 'Gediz-75' number 13 demonstrated a different allele size than the other samples within WMS11 and WMS120 loci. At WMS 6, 'Gediz-5' and -8 , has shown the same allele size and three different genotypes were determined in this population. 'Salihli-92' had a mean PIC value of 0.183 with WMS6 as the most polymorphic locus possessing PIC value of 0.504 . For this genotype, four plant types out of 10 samples were detected within the population. WMS6 was observed to be highly polymorphic loci in case of another cultivar 'Selçuklu-97' also with 0.375 as PIC value.

Clustering for in-variety polymorphism study has shown the similar grouping as with the genotypes (Fig. 2). In this grouping also, 'Diyarbakir-81' with 'Salihli-92' and 'Ege-88'

Tab. 5. Allele sizes of genotypes in each population at seven microsatellite loci. Along with the names of the genotypes, the numbers after slash are the individual plant numbers for each plant variety (population)

\begin{tabular}{|c|c|c|c|c|c|c|c|}
\hline \multirow{2}{*}{$\begin{array}{l}\text { Individual } \\
\text { Genotypes }\end{array}$} & \multicolumn{7}{|c|}{ Markers } \\
\hline & WMS5 & WMS6 & WMS11 & WMS30 & WMS46 & WMS120 & WMS131 \\
\hline 'Diyarbakır-4' & 161 & $205 / 247$ & 222 & 212 & 179 & 162 & 153 \\
\hline 'Diyarbakır-5' & 163 & $201 / 205$ & 222 & 212 & 173 & 162 & 159 \\
\hline 'Diyarbakır-8' & 163 & $199 / 205$ & 222 & 212 & 173 & 162 & 159 \\
\hline 'Diyarbakı1-9' & 163 & $201 / 205$ & 222 & 212 & 169 & 162 & 159 \\
\hline 'Diyarbakır-10' & 160 & $205 / 247$ & 222 & 212 & 179 & 162 & 155 \\
\hline 'Diyarbakır-11' & 163 & $201 / 205$ & 222 & 212 & 173 & 162 & 159 \\
\hline 'Diyarbakır-12' & 161 & $205 / 247$ & 222 & 212 & 179 & 162 & 155 \\
\hline 'Diyarbakır-14' & 163 & $201 / 205$ & 222 & 212 & 173 & 162 & 159 \\
\hline 'Diyarbakır-15' & 171 & $205 / 247$ & 222 & 212 & 181 & 162 & 155 \\
\hline 'Diyarbakır-A' & 163 & 201/209 & 220 & 212 & 169 & 162 & 149 \\
\hline 'Ege-1' & 171 & $199 / 213$ & 220 & 216 & 181 & 162 & 159 \\
\hline 'Ege-2' & 171 & $199 / 213$ & 220 & 216 & 181 & 162 & 159 \\
\hline 'Ege-3' & 171 & $199 / 213$ & 220 & 216 & 181 & 162 & 159 \\
\hline 'Ege-4' & 171 & $199 / 213$ & 220 & 216 & 181 & 162 & 159 \\
\hline 'Ege-5' & 171 & $199 / 211$ & 220 & 214 & 181 & 162 & 159 \\
\hline 'Ege-7' & 171 & $199 / 213$ & 220 & 216 & 181 & 162 & 159 \\
\hline 'Ege-8' & 171 & $199 / 213$ & 220 & 216 & 181 & 162 & 159 \\
\hline 'Ege-10' & 171 & $199 / 211$ & 222 & 214 & 181 & 162 & 159 \\
\hline 'Ege-11' & 171 & $199 / 211$ & 220 & 216 & 181 & 162 & 159 \\
\hline 'Ege-A' & 171 & $199 / 213$ & 220 & 216 & 181 & 162 & 159 \\
\hline 'Gediz-3’' & 166 & $201 / 211$ & 222 & 214 & 181 & 159 & 159 \\
\hline 'Gediz-5' & 166 & $201 / 201$ & 222 & 214 & 181 & 159 & 159 \\
\hline 'Gediz-7’' & 166 & $201 / 211$ & 222 & 214 & 181 & 159 & 159 \\
\hline 'Gediz-8’' & 166 & $201 / 201$ & 222 & 214 & 181 & 159 & 159 \\
\hline 'Gediz-9’' & 166 & $201 / 211$ & 222 & 214 & 181 & 159 & 159 \\
\hline 'Gediz-11' & 166 & $201 / 211$ & 222 & 214 & 181 & 159 & 159 \\
\hline 'Gediz-12' & 166 & $201 / 211$ & 222 & 214 & 181 & 159 & 159 \\
\hline ‘Gediz-13’ & 166 & $201 / 205$ & 192 & 214 & 181 & 132 & 159 \\
\hline 'Gediz-14' & 166 & $201 / 211$ & 222 & 214 & 181 & 159 & 159 \\
\hline 'Gediz-A' & 166 & $201 / 211$ & 222 & 214 & 181 & 159 & 159 \\
\hline 'Salihli-1' & 163 & 199/211 & 222 & 212 & 181 & 159 & 159 \\
\hline 'Salihli-2' & 162 & $199 / 205$ & 222 & 212 & 173 & 162 & 159 \\
\hline 'Salihli-3' & 163 & $199 / 205$ & 222 & 212 & 173 & 162 & 159 \\
\hline 'Salihli-4' & 163 & $201 / 205$ & 222 & 212 & 173 & 162 & 159 \\
\hline 'Salihli-5' & 163 & $199 / 205$ & 222 & 212 & 173 & 162 & 159 \\
\hline 'Salihli-6' & 163 & $199 / 205$ & 222 & 212 & 173 & 162 & 159 \\
\hline 'Salihli-7' & 163 & $199 / 205$ & 222 & 212 & 173 & 162 & 159 \\
\hline 'Salihli-9' & 162 & $199 / 205$ & 222 & 212 & 173 & 162 & 159 \\
\hline 'Salihli-10' & 162 & $199 / 205$ & 222 & 212 & 173 & 162 & 159 \\
\hline 'Salihli-A' & 163 & $199 / 205$ & 222 & 212 & 173 & 162 & 159 \\
\hline 'Selçuklu-1' & 171 & $203 / 247$ & 228 & 216 & 169 & 162 & 159 \\
\hline 'Selçuklu-2' & 171 & $203 / 247$ & 228 & 216 & 169 & 162 & 159 \\
\hline 'Selçuklu-3' & 171 & $203 / 247$ & 228 & 216 & 169 & 162 & 159 \\
\hline 'Selçuklu-4' & 171 & $203 / 247$ & 228 & 216 & 169 & 162 & 159 \\
\hline 'Selçuklu-5' & 171 & $203 / 247$ & 226 & 214 & 169 & 162 & 159 \\
\hline 'Selçuklu-6' & 171 & $203 / 247$ & 228 & 216 & 169 & 162 & 159 \\
\hline 'Selçuklu-7’' & 171 & $203 / 247$ & 228 & 216 & 169 & 162 & 159 \\
\hline 'Selçuklu-8' & 171 & $203 / 247$ & 228 & 216 & 169 & 162 & 159 \\
\hline 'Selçuklu-9' & 171 & $203 / 247$ & 228 & 216 & 169 & 162 & 159 \\
\hline 'Selçuklu-10' & 171 & $203 / 247$ & 228 & 216 & 169 & 162 & 159 \\
\hline
\end{tabular}


with 'Selcuklu-97' has shown a closer association. 'Gediz-75' was found to be similarly associated with the two groups of 'Diyarbakir-81' with 'Salihli-92' and 'Ege-88' with 'Selcuklu97'. However, some of the subpopulations, 'Selcuklu-97' number 10 and 'Salihli-92' number 1 were clustered with 'Gediz-75' group showing the genetic association.

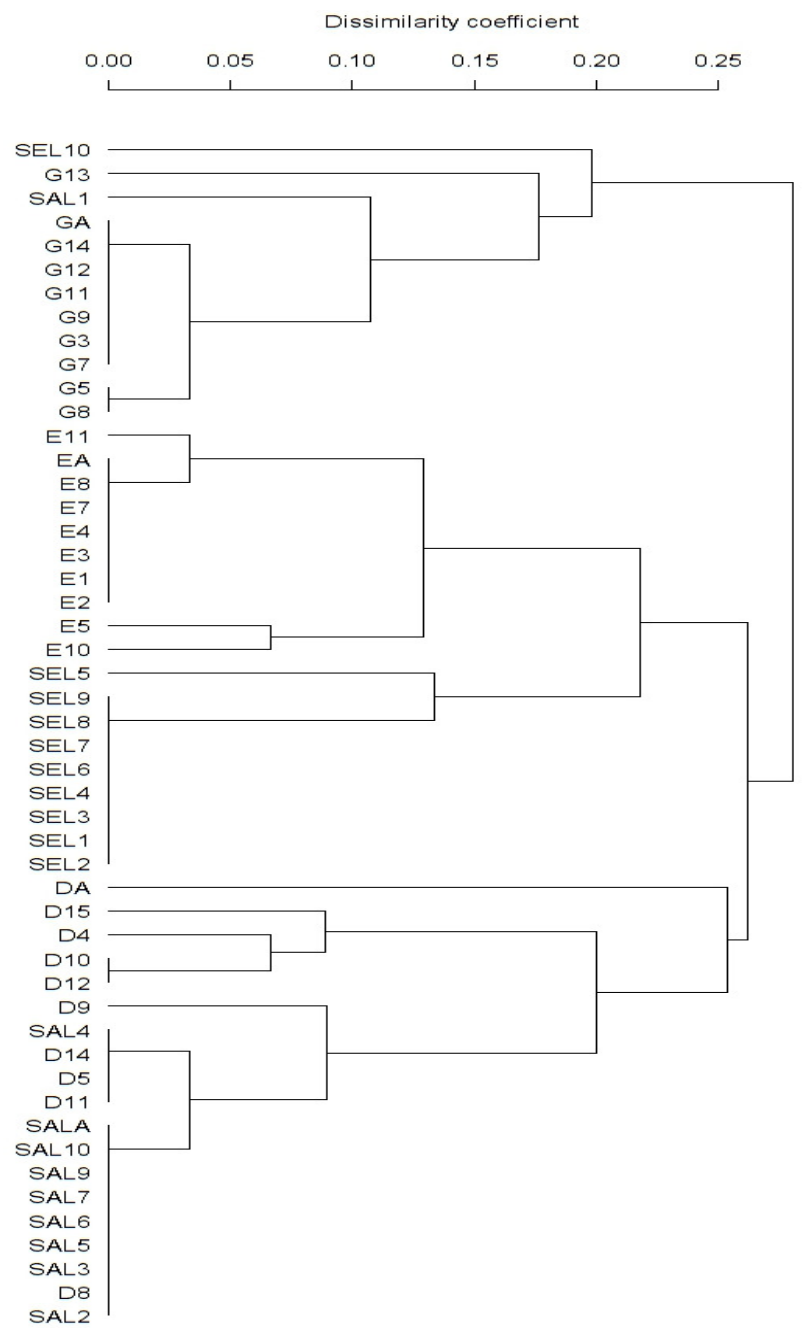

Fig. 2. Clustering of subpopulations of genotypes based on $\mathrm{R}$ software (where D- 'Diyarbakir-81', E- 'Ege-88', G- 'Gediz-75', SAL- 'Salihli-92', SEL- 'Selçuklu-97’)
In our study, two Scatterplots have been obtained using $\mathrm{R}$ software to demonstrate the genetic association among and within the subpopulations of the genotypes. One was based on 0-1 matrix data and another one was based on allelic data. Both the scatterplots were found to be in accordance with each other and with the clusters obtained from the dendrogram (Fig. 3) validating the cluster group results. In scatterplot plot obtained from 0-1 matrix, the first two coordinates explained $31.2 \%$ and $27.7 \%$ information of the total variation, respectively and 'Diyarbakir-81' and 'Salihli-92' were found to be in close association similar to UPGMA dendrogram. While in scatterplot obtained from codominant data, $33.84 \%$ and $28.74 \%$ variation was represented by first two coordinates. Though 10 individual plants were chosen for each of the five genotypes, some of these were not visible in scatterplots due to overlapping, justifying the closer association among them.
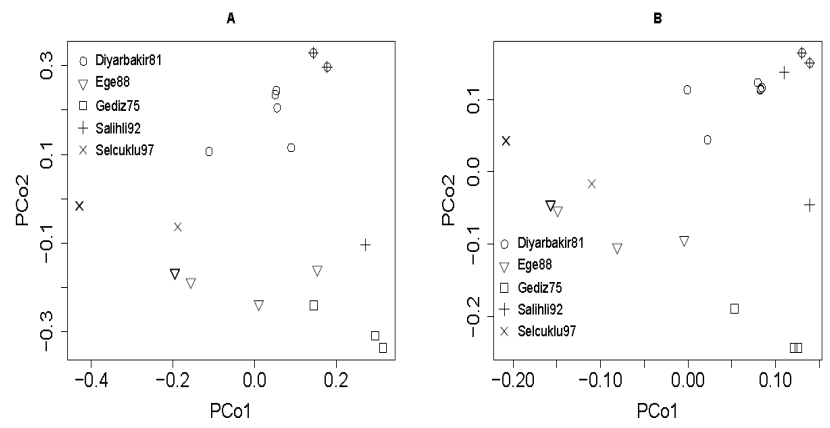

Fig. 3. Two dimensional scatterplot (PCoA) showing the genetic association among the subpopulations of five durum genotypes based on 7 SSR markers. Grouping of subpopulations can be observed. Scatterplot A was based on 0-1 matrix and first two coordinates explained $31.2 \%$ and $27.7 \%$ variation while Scatterplot $\mathrm{B}$ was dependent on co-dominant data and first two coordinates explained $33.84 \%$ and $28.74 \%$ variation

\section{Analysis of molecular variance (AMOVA)}

As mentioned above, 5 populations and 50 individuals were used to execute AMOVA by GenAlEx 6.5 software. Significant genetic variance $(\mathrm{P}<0.010)$ has been obtained within the populations and among the populations (Fig. 4, Tab. 7). The variation among the population reported for the largest share $(76 \%)$ of the total variance, while the differences within the population accounted for $24 \%$ of the whole variation.

Tab. 6. PIC values, number of alleles and maximum length difference between allele sizes in basepair $(\Delta \mathrm{L})$ per locus for each population

\begin{tabular}{|c|c|c|c|c|c|c|c|c|c|}
\hline Genotypes & & $\begin{array}{c}\text { WMS } \\
5 \\
\end{array}$ & $\begin{array}{c}\text { WMS } \\
6 \\
\end{array}$ & $\begin{array}{c}\text { WMS } \\
11 \\
\end{array}$ & $\begin{array}{c}\text { WMS } \\
30 \\
\end{array}$ & $\begin{array}{c}\text { WMS } \\
46 \\
\end{array}$ & $\begin{array}{c}\text { WMS } \\
120 \\
\end{array}$ & $\begin{array}{c}\text { WMS } \\
131 \\
\end{array}$ & Average \\
\hline \multirow{3}{*}{ 'Diyarbakır-81' } & PIC & 0.58 & 0.64 & 0.18 & 0 & 0.7 & 0 & 0.64 & $0.391 \pm 0.31$ \\
\hline & Alleles & 4 & 5 & 2 & 1 & 4 & 1 & 4 & $3 \pm 1$ \\
\hline & $\Delta \mathrm{L}$ & 11 & 48 & 2 & 0 & 22 & 0 & 10 & $13 \pm 17$ \\
\hline \multirow{3}{*}{ 'Ege-88' } & PIC & 0 & 0.527 & 0.18 & 0.32 & 0 & 0 & 0 & $0.147 \pm 0.20$ \\
\hline & Alleles & 1 & 3 & 2 & 2 & 1 & 1 & 1 & $2 \pm 1$ \\
\hline & $\Delta \mathrm{L}$ & 0 & 14 & 2 & 2 & 0 & 0 & 0 & $3 \pm 5$ \\
\hline \multirow{3}{*}{ 'Gediz-75’ } & PIC & 0 & 0.424 & 0.18 & 0 & 0 & 0.18 & 0 & $0.112 \pm 0.16$ \\
\hline & Alleles & 1 & 3 & 2 & 1 & 1 & 2 & 1 & $2 \pm 1$ \\
\hline & $\Delta \mathrm{L}$ & 0 & 10 & 30 & 0 & 0 & 27 & 0 & $10 \pm 13$ \\
\hline \multirow{3}{*}{ 'Salihli-92' } & PIC & 0.42 & 0.504 & 0 & 0 & 0.18 & 0.18 & 0 & $0.183 \pm 0.20$ \\
\hline & Alleles & 2 & 4 & 1 & 1 & 2 & 2 & 1 & $2 \pm 1$ \\
\hline & $\Delta \mathrm{L}$ & 1 & 12 & 0 & 0 & 8 & 13 & 0 & $5 \pm 6$ \\
\hline \multirow{3}{*}{ 'Selçuklu-97’ } & PIC & 0 & 0.375 & 0.18 & 0.18 & 0 & 0 & 0 & $0.105 \pm 0.14$ \\
\hline & Alleles & 1 & 1 & 2 & 2 & 1 & 1 & 1 & $1 \pm 0.5$ \\
\hline & $\Delta \mathrm{L}$ & 0 & 0 & 2 & 2 & 0 & 0 & 0 & $21 \pm 10$ \\
\hline
\end{tabular}


437

Lower variation within the populations facilitates the maintenance of considerable heterozygosity between the populations. So, in agreement with this, comparatively lesser extent of within population variation has been demonstrated by AMOVA results, dendrograms and scatterplots and validated the extent of heterozygosity among the five genotypes.

\section{Percentages of Molecular Variance}

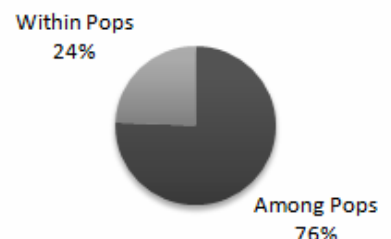

Fig. 4. Analysis of molecular variance (AMOVA) showing variability among and within five Turkish durum wheat populations and subpopulations, respectively

Tab. 7. Analysis of molecular variance (AMOVA) on five Turkish Durum Wheat populations analysed with 7 simple sequence repeat (SSR) markers. Here, Probability, $\mathrm{P}($ rand $>=$ data $)$, for PhiPT is based on permutation across the full data set. $\mathrm{df}=$ degree of freedom, $\mathrm{SS}=$ sum of square, $\mathrm{MS}=$ mean square, Est. Var. $=$ Estimated Variance

\begin{tabular}{cccccc}
\hline \multicolumn{5}{c}{ Summary AMOVA table } \\
\hline $\begin{array}{c}\text { Source of } \\
\text { variation }\end{array}$ & df & SS & MS & $\begin{array}{c}\text { Est. } \\
\text { Var. }\end{array}$ & $\begin{array}{c}\text { Percentage of } \\
\text { variation }\end{array}$ \\
\hline $\begin{array}{c}\text { Among } \\
\text { Pops }\end{array}$ & 4 & 261.680 & 65.420 & 6.338 & $76 \%$ \\
\hline $\begin{array}{c}\text { Within } \\
\text { Pops }\end{array}$ & 45 & 92.000 & 2.044 & 2.044 & $24 \%$ \\
\hline Total & 49 & 353.680 & & 8.382 & $100 \%$ \\
\hline Stat & Value & $\mathrm{P}($ rand $>=$ data $)$ & & \\
\hline PhiPT & 0.756 & 0.010 & & \\
\hline Nm & 0.081 & & & \\
\hline
\end{tabular}

\section{Variations in mineral and protein contents}

The results for mineral constitution and protein content for the explored type durum varieties are summarized in Tab. 8. No much disparity was found in the protein content of the considered genotypes. The protein content was found from $15.17 \%$ to $16.9 \%$. But a noteworthy divergence in the mineral content values among the five genotypes was observed. The concentrations of $\mathrm{Ca}, \mathrm{Cu}, \mathrm{Fe}, \mathrm{K}, \mathrm{Mg}, \mathrm{Mn}, \mathrm{Na}, \mathrm{P}, \mathrm{S}$ and $\mathrm{Zn}$ of durum wheat samples were observed at high levels and the average values were 297.5, 4.9, 28.9, 4334.6, 1611.2, 18.4, 14.2, $3452.9,1350.2$ and $21.0 \mathrm{mg} / \mathrm{kg}$, respectively. $\mathrm{K}$ contents of wheat varieties were found at high levels compared with other elements, followed by P, Mg, S, Ca and Fe. Potassium content varied between 3,976 and $4,749 \mathrm{mg} / \mathrm{kg}$. Phosphorus was found between 2,846 and $4,533 \mathrm{mg} / \mathrm{kg}$. While $\mathrm{Mg}$ concentrations range between 1,404 and $2,110 \mathrm{mg} / \mathrm{kg}, S$ content of grains changed between 1,206 and $1,582 \mathrm{mg} / \mathrm{kg}$. In most of the cases, there were no strong correlation between the content of pairs of the scrutinized nutrients in wheat grain, except for noted strong positive correlation between $\mathrm{Mg}$ and $\mathrm{P}(\mathrm{r}=0.97), \mathrm{Mg}$ and $\mathrm{S}(\mathrm{r}=0.88)$ and $\mathrm{S} \mathrm{v} / \mathrm{s} \mathrm{Na}(\mathrm{r}=0.95)$ (Tab. 9). Strong negative correlation was found between $\mathrm{Na}$ and $\mathrm{Zn}(\mathrm{r}=-0.91)$.
Tab. 8. Mineral $(\mathrm{mg} / \mathrm{kg})$ and protein $(\%)$ content in five durum genotypes

\begin{tabular}{|c|c|c|c|c|c|}
\hline \multirow{2}{*}{ Elements } & \multicolumn{5}{|c|}{ Genotypes/mineral and protein content $($ mean $\pm S D)$} \\
\hline & 'Diyarbakir-81' & 'Ege-88' & ‘Gediz-75’ & 'Salihli-92' & 'Selçuklu-97’ \\
\hline $\mathrm{Ca}^{*}$ & $325.3 \pm 1.2$ & $205.4 \pm 1.8$ & $189.2 \pm 1.1$ & $474.5 \pm 3.6$ & $293.1 \pm 2$ \\
\hline$S^{*}$ & $1341 \pm 15$ & $1322 \pm 3.0$ & $1206 \pm 8$ & $1300 \pm 2$ & $1582 \pm 11$ \\
\hline $\mathrm{Mg}^{*}$ & $1404 \pm 8.0$ & $1457 \pm 6$ & $1462 \pm 8$ & $1624 \pm 14$ & $2110 \pm 10$ \\
\hline $\mathrm{P}^{*}$ & $2846 \pm 19.6$ & $3272 \pm 23.8$ & $3310 \pm 13.5$ & $3303 \pm 16.9$ & $4533 \pm 47.9$ \\
\hline $\mathrm{K}^{*}$ & $4335 \pm 42$ & $3992 \pm 7$ & $4621 \pm 33$ & $3976 \pm 22$ & $4749 \pm 22$ \\
\hline $\mathrm{Na}^{* *}$ & $13.1 \pm 3.35$ & $14.9 \pm 1.99$ & $10.9 \pm 2.68$ & $13.6 \pm 3.19$ & $18.5 \pm 1.90$ \\
\hline $\mathrm{Cu}^{* *}$ & $3.55 \pm 0.06$ & $3.85 \pm 0.06$ & $5.77 \pm 0.09$ & $5.15 \pm 0.05$ & $5.98 \pm 0.09$ \\
\hline $\mathrm{Mn}^{* *}$ & $14.39 \pm 0.09$ & $17.63 \pm 0.04$ & $19.67 \pm 0.06$ & $23.07 \pm 0.20$ & $17.36 \pm 0.12$ \\
\hline $\mathrm{Zn}^{* *}$ & $21.62 \pm 0.12$ & $19.22 \pm 0.22$ & $23.45 \pm 0.18$ & $22.25 \pm 0.13$ & $18.66 \pm 0.13$ \\
\hline $\mathrm{Fe}^{* *}$ & $24.91 \pm 0.10$ & $28.62 \pm 0.16$ & $21.23 \pm 0.11$ & $39.04 \pm 0.13$ & $30.87 \pm 0.20$ \\
\hline Proteins & $15.54 \pm 0.48$ & $15.75 \pm 0.69$ & $16.91 \pm 0.33$ & $15.17 \pm 1.18$ & $15.7 \pm 0.48$ \\
\hline
\end{tabular}

Tab. 9. Pearson correlation coefficients between mineral and protein content of durum wheat varieties

\begin{tabular}{|c|c|c|c|c|c|c|c|c|c|c|}
\hline & $\mathrm{Ca}$ & $\mathrm{Cu}$ & $\mathrm{Fe}$ & $\mathrm{K}$ & $\mathrm{Mg}$ & $\mathrm{Mn}$ & $\mathrm{Na}$ & $P$ & $S$ & $\mathrm{Zn}$ \\
\hline $\mathrm{Cu}$ & 0.01 & & & & & & & & & \\
\hline $\mathrm{Fe}$ & $0.82^{*}$ & 0.12 & & & & & & & & \\
\hline K & -0.39 & 0.61 & -0.51 & & & & & & & \\
\hline $\mathrm{Mg}$ & 0.18 & 0.66 & 0.39 & 0.51 & & & & & & \\
\hline $\mathrm{Mn}$ & 0.44 & 0.51 & 0.59 & -0.32 & 0.08 & & & & & \\
\hline $\mathrm{Na}$ & 0.11 & 0.20 & 0.42 & 0.20 & $0.84^{*}$ & -0.20 & & & & \\
\hline P & -0.05 & 0.71 & 0.24 & 0.58 & $096^{+m}$ & 0.07 & $081^{*}$ & & & \\
\hline$S$ & 0.12 & 0.25 & 0.29 & 0.41 & $0.88^{* *}$ & -0.33 & $0.95^{*}$ & $081^{*}$ & & \\
\hline $\mathrm{Zn}$ & 0.15 & 0.10 & -0.23 & -0.03 & -057 & 039 & $-0.90^{* 4}$ & .060 & -0.80 & \\
\hline Protein & -0.78 & 0.38 & -0.79 & 0.56 & -021 & -004 & -047 & -001 & -04 & 039 \\
\hline
\end{tabular}

\section{Discussion and conclusions}

By using different microsatellite primer sets, genotypes were successfully differentiated (Fig. 1). They were divided into two major groups. 'Selçuklu-97' and 'Ege-88' were clustered together and the other three varieties 'Diyarbakir81', 'Gediz-75' and 'Salihli-92' were grouped collectively but 'Diyarbakir-81' and 'Salihli-92' were the most closest ones. In another study, similar genetic association among these genotypes was shown by Karaca and Izbirak (2008) using RAPD and ISSR markers. In their study, 'Diyarbakir-81' and 'Ege-88' along with 'Gediz-75' and 'Salihli-92' were found to be closely associated. As per our results, WMS6 with the PIC value of 0.887 was the most polymorphic locus for the genotypes and it was enough for distinguishing all of them. Roder et al. (1995) reported that WMS6 amplifies two diverse loci, one in $4 \mathrm{~B}$ and another in $4 \mathrm{D}$ chromosome. Due to the selection of durum wheat, there was no amplification of genome D in our work.

As mentioned earlier, seven sets of Wheat Microsatellite (WMS) primers had been selected for the study, whose sequences and chromosome positions of the augmented loci have already been revealed (Roder et al., 1995; Plaschke et al., 1995). Similar set of wheat microsatellite primers have been used by Dograr et al. (2000) for discriminating winter type Turkish durum wheat varieties and found polymorphism information content values in the range of $0.609-0.872$. Although limited number of diversity studies has been done on Turkish durum wheat using microsatellite markers, our results were comparable to several other diversity experiments 
performed on several wheat populations utilizing similar SSR loci. However, Khlestkina et al. (2004) have claimed that PIC values must be considered as the variables changing according to the experimental material and time of conducting experiment. In our study, WMS5 (0.611), WMS46 (0.666) and WMS120 (0.500) was found to provide less polymorphism information content in comparison to the values obtained by Mondini et al. (2010) in Ethiopian durum wheat. However, PIC values obtained from WMS11 (0.500), WMS46 (0.666) and WMS131 (0.227) were almost similar to the values revealed from these loci by Ahmad, 2002 in bread wheat genotypes of diverse origin.

Also, both the UPGMA Dendrograms and Principle Coordinate Analysis based plots were found to be closely associated to each other. For bootstrap analysis, Felsenstein (1985) suggested that only the clusters with higher bootstrap P values (95\% or more) can be recognized as robust. In our case, 'Diyarbakir-81' and 'Salihli-92' have 100\% bootstrap P values thus justifying the confidence limits of the dendrogram.

It is necessary to select genetically distant genotypes for a successful breeding programme and hence, verifying their association. SSR markers used in the study were proved to be capable of differentiating both genotypes and subpopulations. Outlier variety, 'Salihli-92' number 1 in subpopulations dendrogram have separated apart from their main group due to the presence of specific alleles at WMS6, WMS46 and WMS120 loci of length 211,181 and 159 bp respectively. Similarly, 'Gediz-75' number 13 showed partition from rest of their genotypes by the existence of 205, 192 and $132 \mathrm{bp}$ alleles at WMS6, WMS11 and WMS120 respectively. Also, some of the subpopulations of 'Salihli-92' and 'Diyarbakir81' group like 'Salihli-92' number 4 and 'Diyarbakir81 'number 8 have shown mixing with each other due to the presence of same alleles at number of loci. It is also noteworthy that although most of the subpopulations have shown similar grouping as genotypes, 'Diyarbakir-81' has shown significant variation among the subpopulations especially at locus WMS5, WMS6, WMS46 and WMS131. However, it should be noticed that dendrogram results for 'Diyarbakir-81' and 'Salihli-92' genotypes with $89 \%$ similarity and $100 \%$ bootstrap values could be different if outlier subpopulation 'Salihli-92' number 1 would have been considered for the analysis. In addition, utilization of these outlier populations can be of great advantage in successful breeding programme. As the heterozygosity of a population is determined by the collection of alleles, WMS6 locus was found efficiently responsible for maintaining the variance in the genotypes.

Though varieties used in the experiment had shown significant genetic variation according to all the statistical analyses performed, the distributed location of cultivars demonstrated less comparative polymorphism. As wheat is a self-pollinating species, variations within the populations can be easily found as a result of mixing. So, for the proper introduction of characters by breeders, uniformity of seeds should be checked prior to the crosses/hybridization. The information on the polymorphic loci and the related large size difference (as in case of WMS6) would serve as the support for breeders for the selection of appropriate parents. The molecular portion of the study was an attempt towards the validation of interspecific and intraspecific polymorphism of
Turkish Durum wheat. This in future can help for the choice of appropriate parents which consecutively may support the breeding programs.

Also, momentous differences in iron, calcium, potassium, copper, magnesium, sodium, manganese, sulphur, phosphorus, and zinc were found among the chosen genotypes. 'Selçuklu-97' offered higher copper, potassium, phosphorus magnesium, sodium and sulphur content as compared to other varieties. The occurrence of strong positive correlations between phosphorus and magnesium in examined varieties could have imperative inference for the propagation of new varieties containing elevated levels of both nutrients.

Genetic origin may be the major cause of these discrepancies in the mineral content. Minerals that are greatly required in human food supply are present in adequate quantity in the examined durum varieties. Although nutrient content in wheat is controlled by soil factors, climatic conditions and cultivation methods, mineral composition in wheat grains is basically a varietal attribute. So, despite of the environmental influences, persistent efforts are needed to search innovative genetic resources of durum wheat genotypes that are augmented with essential nutrients and protein. These selected and recommended durum wheat genotypes may be utilized in the future to attain more nutritionally and genetically rich wheat food.

\section{Acknowledgement}

We are highly thankful to Dr. Ahmet Yildırım, Gaziosmanpasa University, Tokat for providing 'Selcuklu-97' and to Aegean Agricultural Research Institute, Izmir for making rest four varieties and their pedigrees available.

\section{References}

Ahmad M (2002). Assessment of genomic diversity among wheat genotypes as determined by simple sequence repeats. Genome 45:646-651.

Al Khanjari S, Hammer K, Buerkert A, Roder MS (2007). Molecular diversity of Omani wheat revealed by microsatellites. Genet Resour Crop Evol 54:1407-1417.

Anderson JA, Churchill GA, Autrique JE, Tanksley SD, Sorrells ME (1993). Optimizing parental selection for genetic linkage maps. Genome 36:181-186.

Amer IMB, Borner A, Roder MS (2001). Detection of genetic diversity in Lybian wheat genotypes using wheat microsatellite markers. Genet Resour Crop Evol 48:579585.

Blanco A, Bellomo MP, Cenci A, De Giovanni C, D’Ovidio R, Iacono E, Laddomada B, Pagnotta MA, Porceddu E, Sciancalepore A, Simeone R, Tanzarella OA (1998). A genetic linkage map of durum wheat. Theor Appl Genet 97(5-6):721728.

Cakmak I, Ozkan H, Braun HJ, Welch RM, Romheld V (2000). Zinc and iron concentrations in seeds of wild, primitive, and modern wheats. Food Nutr B 21:401-403. 
439

Clarke JM, Norvell WA, Clarke FR, Buckley WT (2002). Concentration of cadmium and other elements in the grain of near-isogenic durum lines. Can J Anim Sci 82:27-33.

Colomba MS, Gregorini A (2011). Genetic diversity analysis of the durum wheat Graziella Ra, Triticum turgidum L. subsp. durum (Desf.) Husn. (Poales, Poaceae). Biodiver J 2:73-84.

Dikeman E, Pomeranz Y, Lai FS (1982). Minerals and protein contents in hard red winter wheat. Cereal Chem 59:139-142.

Dograr N, Akin-Yalin S, Akkaya MS (2000). Discriminating durum wheat cultivars using highly polymorphic simple sequence repeat DNA markers. Plant Breeding 119:360-362.

Donini P, Law JR, Koebner RM, Reeves JC, Cooke RJ (2000). Temporal trends in the diversity of UK wheat. Theor Appl Genet 100:912-917.

Feil B, Fossati D (1995). Mineral composition of triticale grains as related to grain yield and grain protein. Crop Sci 35:14261431.

Felsenstein J (1985). Confidence limits on phylogenies: an approach using the bootstrap. Evolution 39:783-791.

Figliuolo G, Mazzeo M, Greco I (2007). Temporal variation of diversity in Italian durum wheat germplasm. Genet Resour Crop Evol 54:615-626.

Foy CD (1992). Soil chemical factors limiting plant root growth. Adv Soil Sci 19:97-149.

Galan J, Haguenauer-Tsapis R (1997). Ubiquitin lys63 is involved in ubiquitination of a yeast plasma membrane protein. $\mathrm{E} \mathrm{M} \mathrm{B}$ OJ 16:5847-5854.

Graham RD, Rovina AD (1984). A role for manganese in the resistance of wheat to take-all. Plant Soil 78:441-444.

Graham RD, Webb MJ (1991). Micronutrients and resistance and tolerance to disease. pp 329-370, In: Mortwedt JJ, Cox FR, Shuman LM, Welch RM (Eds.) Micronutrients in Agriculture. 2nd ed. Soil Science Society of America, Madison.

Karaca M, Izbirak A (2008). Comparative analysis of genetic diversity in Turkish durum wheat cultivars using RAPD and ISSR markers. J Food Agri Environ 6:219-225.

Khan MK, Pandey A, Choudhary S, Hakki EE, Akkaya MS, Thomas G (2014). From RFLP to DArT: molecular tools for wheat (Triticum spp.) diversity analysis. Genet Resour Crop Ev 61:1001-1032

Khlestkina EK, Huang XQ, Quenum FJB, Chebotar S, Roeder MS, Borner A (2004). Genetic diversity in cultivated plantsloss or stability? Theor Appl Genet 108:1466-1472.

Korkut KZ, Bilgin O, Baser I, Saglam N (2007). Stability of Grain Vitreousness in Durum Wheat (Triticum durum L. Desf.) Genotypes in the North-Western Region of Turkey. Turk J Agric Fore 31:313-318.

Lahner B, Gong J, Mahmoudian M, Smith EL, Abid KB, Rogers EE, Guerinot ML, Harper JF, Ward JM, McIntyre L, Schroeder JI, Salt DE (2003). Genomic scale profiling of nutrient and trace elements in Arabidopsis thaliana. Nat Biotechnol 10:1215-1221.

Landjeva S, Korzun V, Tsanev V, Vladova R, Ganeva G (2006).
Distribution of the wheat-rye translocation 1RS.1BL among bread wheat varieties of Bulgaria. Plant Breed 125:102-104.

Lynch J (1995). Root architecture and plant productivity. Plant Physiol 109:7-13.

Maccaferri M, Sanguineti MC, Natoli V, Ortega JLA, Ben Salem M, Bort J, Chenenaouia C, De Ambrogioa E, del Morala LG, De Montisa A, El-Ahmeda A, Maaloufa F, Machlaba H, Moraguesa M, Motawaja J, Nachita M, Nserallaha N, Ouabboua H, Royoa C, Tuberosa R (2006). A panel of elite accessions of durum wheat (Triticum durum Desf.) suitable for association mapping studies. Plant Gen Res 4:79-85.

McGrath SP (1985). The effects of increasing yields on the macroand microelement concentrations and off-takes in the grain of winter wheat. J Sci Food Agric 36:1073-1083.

Mondini L, Farina A, Porceddu E, Pagnotta MA (2010). Analysis of durum wheat germplasm adapted to different climatic conditions. Ann Appl Biol 156:211-219.

Nachit MM, Elouafi I, Pagnotta MA, El saleh A, lacono E, Labhilili M, Asbati A, Azrak M, Hazzam H, Benscher D, Khairallah M, Ribaut JM, Tanzarella OA, Porceddu E, Sorrells ME (2001). Molecular linkage map for an intraspecific recombinant inbred population of durum wheat (Triticum turgidum L. var. durum). Theor Appl Genet 102:177-186.

Plaschke J, Ganaland MW, Röder MS (1995). Detection of genetic diversity in closely related bread wheat using microsatellite markers. Theor Appl Genet 91:1001-1007.

Prasad M, Varshney RK, Roy JK, Balyan HS, Gupta PK (2000). The use of microsatellites for detecting DNA polymorphism, genotype identification and genetic diversity in wheat. Theor Appl Genet 100:584-592.

Roder MS, Plaschke J, Konig SU, Börner A, Sorrells ME, Tanksley SD, Ganal MW (1995). Abundance variability and chromosomal location of microsatellites in wheat. Mol Gen Genet 246:327-333.

Rohlf FJ (1998). NTSYS-pc Numerical taxonomy and multivariate analysis system. Version2.02e. Applied Biostatistics Inc., Setauket, New York.

Saghai-Maroof MA, Soliman KM, Jorgensen RA, Allard RW (1984). Ribosomal DNA spacer-length polymorphisms in barley: Mendelian inheritance, chromosomal location, and population dynamics. Proc Nat Acad Sci 81:8014-8018.

Sneath PHA, Sokal RR (1973). Numerical taxonomy; the principles and practice of numerical classification. Freeman WH, San Francisco. p 573.

Tautz D, Trick M, Dover GA (1986). Cryptic simplicity in DNA is a major source of genetic variation. Nature 322:652-656.

Todorovska E, Abumhadi N, Kamenarova K, Zheleva D, Kostova A, Christov N, Alexandrova N, Jacquemin JM, Anzai H, Nakamura C, Atanassov A (2005). Biotechnol Biotechnol Equip 19:91-104.

Zohary D, Hopf M (1993). Domestication of plants in the old World - The origin and spread of cultivated plants in West Asia, Europe, and the Nile Valley. Clarendon Press, Oxford. 